\title{
Self-regulated Learning Model Affects Students' Mathematical Conceptual Understanding and Self-confidence in terms of Cognitive Styles
}

\section{Mahayani, N. P. L1 ${ }^{*}$, Astawa, I. W. P2, Suharta, I. G. P3}

${ }^{123}$ Mathematics Education Postgraduate Study Program, Faculty of Mathematics and Natural Sciences, Universitas Pendidikan Ganesha, Singaraja, Indonesia

\begin{tabular}{|c|c|}
\hline A R T I C L E I N F O & A B S T R A C T \\
\hline $\begin{array}{l}\text { Article history: } \\
\text { Received } 18 \text { December } \\
2020 \\
\text { Received in revised } \\
\text { Form } 06 \text { January } 2021 \\
\text { Accepted } 1 \text { February } 2021 \\
\text { Available online } 09 \\
\text { February } 2021\end{array}$ & $\begin{array}{l}\text { The main problem in mathematics learning is to form students' understanding } \\
\text { and self confidence. The aim of this study is to analyze the impact of self- } \\
\text { regulated learning model on conceptual understanding and self-confidence in } \\
\text { terms of cognitive styles. This study was a quasi-experimental study which } \\
\text { applies treatment by level design, where the treatment is learning model for } \\
\text { students with different cognitive style level. The samples of the study are } 80 \\
\text { students in four classes, who are selected using cluster random sampling }\end{array}$ \\
\hline $\begin{array}{l}\text { Keywords: } \\
\text { Self-regulated, Self- } \\
\text { confidence, Mathematics }\end{array}$ & $\begin{array}{l}\text { understanding test in the form of essay test. While the data on the students' self- } \\
\text { confidence are collected using questionnaires. The data collected are anayzed } \\
\text { using manova. The results of the study indicate that self-regulated learning has } \\
\text { positive impact on the students' conceptual understanding and self-confidence } \\
(F=8,796 ; p<0,05) \text {. Thus, it could be concluded that learning model and } \\
\text { cognitive style give significant impact on the students' conceptual understanding } \\
\text { and self-confidence in terms of cognitive styles. }\end{array}$ \\
\hline
\end{tabular}

\begin{abstract}
A B S T R A C T
The main problem in mathematics learning is to form students' understanding regulated learning model on conceptual understanding and self-confidence in terms of cognitive styles. This study was a quasi-experimental study which applies treatment by level design, where the treatment is learning model for sampling confidence are collected using questionnaires. The data collected are anayzed using manova. The results of the study indicate that self-regulated learning has positive impact on the students' conceptual understanding and self-confidence cognitive style give significant impact on the students' conceptual understanding and self-confidence in terms of cognitive styles.
\end{abstract}

\section{Introduction}

Mathematics is a part of science that has an important role in human lives. Every part of life involves mathematical roles and functions and children need direct experiences with them to understand its importance in their lives. Mathematics is not merely counting, but also a process of forming understanding. This understanding is important for humans to solve real life problems (Daryanto, 2005; Susanti et al., 2012)

Understanding is a mental activity that connects someone's prior knowledge and new experience so that he/she can represent concepts in the forms of pictures, graphics, tables or a mathematical equation (Anwar et al., 2016; McCluskey et al., 2016). Understanding emphasizes connections and an operation to direct someone's capacity in thinking logically, such as: analysing, proving, evaluating, explaining, concluding, justifying and generalizing. Those skills will support students in developing better learning ability. Further, (Ceran \& Ates, 2020; Ningsih, 2016) mention that learning by developing understanding will give benfits as follows: (1) developing ability to think logically; (2) being able to use their knowledge in different levels and; (3) being able to state a problem using their own words; (4) being able to build an analogy; and (5) building mental power in the form of self-confidence.

Self-confidence is a dimension to carry out self-evaluation for someone to recognize good and bad things within him/herself (Bekomson et al., 2020; Bingol et al., 2019). Self-confidence is also said as selfesteem, where someone has a value or meaning in the eyes of others because he/she has an ability to solve problems. The future-oriented faith related to an individual's ability is expected to be displayed when necessary. Self-confidence can control someone to act according to the existing situation. Strong self-confidence will enable someone to easily make friends in any environment, own tolerance, think positively, and have firm stance in taking actions.

Someone's self-confidence varies and is affected by certain dimensions. The dimensions that affect self-confidence are: (a) Magnitude, related to someone's confidence whether or not he/she can do something; (b) Strength, related to the power of someone's confidence in the ability that he/she has; dan 
(c) Generality, related to someone's confidence in his/her ability to carry out various tasks in different conditions (Bingol et al., 2019; Ghufron \& Risnawati, 2011).

Self-confidence can be formed by four processes (Hazadiyah et al., 2012; Wang et al., 2018). The first one is cognitive process. Cognitive process is related to something that is constructed in the cognitive structure. The results of this structure will give direction about what someone needs to do. The confidence/faith that someone has will influence him/her in interpreting situation. The second one is motivation process. The motivation within someone will support him/her to take actions for the achievement of his/her goals. The third one is affection process. Affection is often said as an emotional or psychiatric factor. Someone's level of calmness will form his/her self-confidence. The fourth one is selection process. Someone's ability in selecting options with his/her cognitive consideration will form higher self-confidence.

However, in reality, students' conceptual understanding and self-confidence in learning mathematics is still low. If they are asked to express their opinions or ideas, they lack of courage. This is caused by their low conceptual understanding. It makes them not confident in their learning process. As a result, mathematics learning becomes a burden for students and learning process becomes tense. Students are not comfortable in following the learning process and tend to fail in constructing their knowledge. Therefore, there needs to be a learning method that will help students to feel secured, comfortable and happy in learning.

Self-regulated learning can be one of the efforts to rehabilitate the existing mathematics learning process. Self-regulation is an ability to manage the knowledge that someone has using effective and efficient learning strategies as well as understanding the exact condition to use the knowledge (Abdul \& Abidha, 2016; Cetin, 2017). In addition, (Melissa, 2016; Qohar \& Sumarmo, 2017) explain that selfregulation process is an activity to grow motivation in the effort to build self-confidence by controlling someone's ability and environment that support learning process. An effective learning environment, both physical and non-physical, can be built by students independently so that they can gain comfort in learning.

Self-regulation is an activity to effectively manage students' learning independently to discover causal relationship of the concepts that they learn. The management of the learning activity can be done through monitoring and evaluation process on the information obtained. Self-regulation that is done before conducting learning is to determine what exactly the objective of the learning. Self-regulation during the learning process is done to ensure that the learning process is in line with the learning objective. Self-regulation after the learning is conducted is to reflect on the learning and measure the achievement level of the objective that has been set (Melissa, 2016; Tezci et al., 2016). The feedback that is resulted then becomes the base for the following activities. Self-regulation activity is like a continuous cycle so that the objective is achieved.

Self-regulation starts the process of analysing problems and objectives. To achieve the objectives, a plan, both in physical and non-physical aspects is prepared. The plan then is implemented to gain results. Observation and investigation processes are done during the implementation to find out the effectivity of the process. If the results are not as expected, there will be modifications on the plan. The results of the modifications then are implemented. This process is continuously done by the students. They manage every step independently. (Cetin, 2017; Fatimah et al., 2020) state that there are seven main activities of self-regulated learning. They are: (1) Analyze; (2) Plan; (3) Implement; (4) Comprehend; (5) Problem solving; (6) Evaluate; dan (7) Modify.

This study is supported by some relevant researches: (1) a research done by (Melissa, 2016) shows that self-regulation can build students' self-motivation in learning; (2) a research conducted by (Cetin, 2017) indicates that self-regulation can revise perception in learning; (3) a research by (Laura \& Phil, 2018) shows that self-regulation can build students' self-confidence; (4) a research done by (Abdul \& Abidha, 2016) shows that self-regulation using computated mathematics learning materials results in good learning independence; (5) a research by (Woottipong, 2020) indicates that self-regulated strategy results in efficacy and performance in writing.

The aim of this study is to analyse the impact of self-regulated learning on conceptual understanding and self-confidence in terms of cognitive style. Cognitive style is divided into field independent (FI) and field dependent (FD). This study is different from previous studies that this study will reveal the simultenous impact of self-regulated learning on conceptual understanding and selfconfidence in terms of students' cognitive styles. 


\section{Method}

This study is a quasi-experimental study as not all the experimental variables and conditions are strictly managed and controlled (Djaali, 2011; Nazir, 2003). It was conducted by applying self-regulated learning model treatment to the experimental group and conventional learning model to the control group in terms of the cognitive style level. The research design applied was non-equivalent control group design where the treatment to the experimental and control groups were determined by the researchers.

This study was conducted in class X SMA Negeri (Senior High School) 1 Selat in the academic year 2020/2021. The number of the research population was 301 students in 9 classes with equal mathematical ability. Four classes were chosen as samples; selected using cluster random sampling technique. X MIPA 1 and X MIPA 3 were chosen as experimental classes, X MIPA 2 and X MIPA 4 are chosen as contral classes. All four classes were given Cognitive Style Test (GEFT) which was developed by Philip K. Oltman, Evelyn Raskin, and Herman A. Witkin with reliability index 0,92 (Candiasa, 2010). As a result, it was discovered that 40 students had FI cognitive style and 40 other had FD cognitive style. There were 80 samples in total.

Conceptual understanding was measured by using conceptual understanding test in the form of essay test with 10 questions. Self-confidence was measured by using questionnaires with Likert model. Conceptual understanding test and self-confidence questionnaires were tried out to determine the item internal consistency and the reliability index of the instrument.

The data analysis technique applied was Multivariat Analysis of Variance (MANOVA) which was preceded by pre-requisite tests namely bivariate normality test, variance-covariance matrix homogeneity test, and correlation test between the dependent variables. The bivariate normality test was conducted by testing the plot between the Mahalanobis distance and chi-square quantile and their correlation, variancecovariance matrix homogeneity test was conducted by using Box M test, and the correlation between two dependent variables, conceptual understanding and self-confidence, was tested using product-moment correlation test (Candiasa, 2010). All of the tests in this study were conducted with $5 \%$ significance level by using SPSS 25.0 for windows application.

\section{Results and Discussion}

\section{Results}

The summary of the descriptive analysis of the data of conceptual understanding and selfconfidence of each group is presented in Tabel 1 .

Tabel 1. The average of conceptual understanding and self-confidence

\begin{tabular}{ccc}
\hline Variable & Experimental Group & Control Group \\
\hline Conceptual Understanding & 23,98 & 22,05 \\
Self-confidence & 129,83 & 126,90 \\
\hline
\end{tabular}

It can be seen in the table that the average of the conceptual understanding of the self-regulated learning group is 23,98 , which is bigger than average of the conventional learning group, which is 22,05 . So as the self-confidence of the self-regulated learning group. The average is 129,83 , which is bigger than the average of the conventional learning group, that is 126,90 .

The results of the bivariate normality test indicate that the data of conceptual understanding and self-confidence in experimental and control groups have bivariate normal distribution. It is shown by the analysis results that more than $50 \%$ of the scatter chi-square of the chi-square distribution and mahalanobis distance tends to form a straight line as in picture 1 and 2 . 


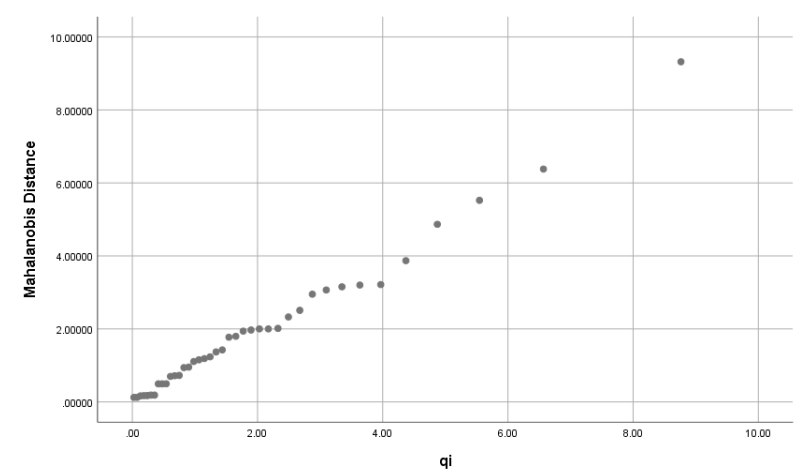

Picture 1. The Chi-square plot of the chi-square distribution and the mahalanobis distance of the experimental groups

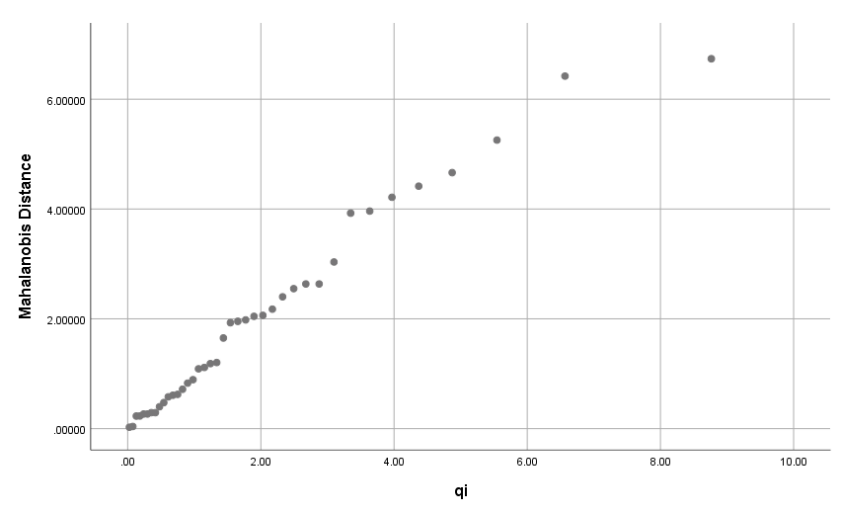

Picture 2. The Chi-square plot of the chi-square distribution and the mahalanobis distance of the control groups

Picture 1 and 2 show that more than 50\% scatter-plot tends to form a straight line. Thus, it can be said that the data on conceptual understanding and self-confidence in experimental and control groups are from population with bivariate normal distribution. This is also strengthened by the correlation value.

The results of the correlation coefficient test between chi-square and mahalanobis distance in experimental groups are presented in Table 2. For control group are presented in Table 3.

Table 2. The Results of the Bivariate Test of Experimental Groups

\begin{tabular}{llrr}
\hline & & Mahalanobis Distance & \multicolumn{1}{c}{ qi } \\
\hline Mahalanobis Distance & Pearson Correlation & 1 & $.994^{* *}$ \\
& Sig. (2-tailed) & & .000 \\
& $\mathrm{~N}$ & 40 & 40 \\
qi & Pearson Correlation & $.994^{* *}$ & 1 \\
& Sig. (2-tailed) & .000 & \\
& $\mathrm{~N}$ & 40 & 40 \\
\hline
\end{tabular}

Table 3. The Results of the Bivariate Test of Control Groups

\begin{tabular}{llrr}
\hline & & Mahalanobis Distance & qi \\
\hline Mahalanobis Distance & Pearson Correlation & 1 & $.984^{* *}$ \\
& Sig. (2-tailed) & & .000 \\
& $\mathrm{~N}$ & 40 & 40 \\
qi & Pearson Correlation & $.984^{* *}$ & 1 \\
& Sig. (2-tailed) & .000 & \\
& $\mathrm{~N}$ & 40 & 40 \\
\hline
\end{tabular}

Table 2 and Table 3 show that the value of pearson correlation between mahalanobis distance and $q i$ is $0,994(p<0,05)$ for experimental groups and $0,984(p<0,05)$ for control groups. This indicates 
that there is a significant correlation between the Mahalanobis distance of the conceptual understanding and self-confidence and chi-square quantile in both groups.

The test of variance-covariance matrix similarity of conceptual understanding and self-confidence between experimental and control groups results in Box $M$ value 0,132 ( $>>0,05)$. This means that the variance-covariance matrices of experimental and control groups are homogeneous. The intercorrelation test indicates that the data of conceptual understanding and self-confidence have correlation as much as 0,369 . This is between $0,30-0,60$, which means that manova can be used as hypothesis analysis.

Hypothesis test by using manova indicates that there is difference between the conceptual understanding and self-confidence between groups of students learning with self-regulated learning model and conventional learning model $(\mathrm{F}=8,796 ; \mathrm{p}<0,05)$. Further, in terms of the level of students' cognitive style, it is found out that there is difference on the conceptual understanding and self-confidence between students with field independent cognitive between those learning with self-regulated learning model and conventional model style $(F=14,773 ; \mathrm{p}<0,05)$. While for students who have field dependent cognitive style, there is no difference on the conceptual understanding and self-confidence between those learning with self-regulated learning model and conventional learning model $(F=14,773 ; p<0,05)$.

\section{Discussion}

The difference on the achievement of the conceptual understanding and self-confidence is caused by the difference on the design of the learning activities. In self-regulated learning, as seen in the learning syntax, the students were given chances to manage the learning environment that they wanted. The syntax of self-regulated learning syntax operationally was practice-based; analyse, plan, implement, comprehend, problem solving, evaluate, and modify. The first phase is analyse, where students analysed and organized the materials and learning concepts learnt in the previous materials. In the learning activity, the students were active and enthusiastic in following the lessons, searching for information, being attentive and they had higher motivation in learning. The second phase was plan, where students planned and designed the learning activities that they wanted. In their learning, the students prepared all equipment needed, searched for relevant sources and found solutions to the problems that they encountered. The third phase is implement, where the students implemented the learning that they had designed. During their learning, the students formed groups and discussed to support the learning based on their worksheets. The fourth phase was comprehending, where students reviewed their understanding. During their learning, the students reviewed their understanding and exchanged ideas with their classmates to find out if their understanding was already in line with the materials that they had learnt or not. The fifth phase was problem solving, where students solved problems and identified the concepts that they had not yet understood. During learning, they asked about the materials that they did not know and the things that they considered important. The sixth phase was evaluating, where the students did self-evaluation on their ability and quality in working on their tasks. In their learning, the students re-checked their works to ensure that they were in line with and achieved the learning objectives. The seventh phase was modifying, where students had to be able to conclude their learning and the conclusion that they drew had to indicate the extent of their ability and conceptual understanding. In their learning, the students had to draw conclusions and tell them. If they were not perfect, other students then added to them so that they could get the right concepts (Situmorang \& Latifah, 2014; Ulfah et al., 2012).

According to (Fatimah et al., 2020; Santyasa, 2012), the base of self-regulated model is constructivism, that teachers design learning that enables students to compile their learning experiences into a meaningful knowledge. In the process of building concepts, students build concept connection between the new knowledge that they obtain and their prior knowledge. To build relationships between concepts, students have to involve actively in the learning process (learning by doing).

Teachers' role in facilitating students' learning is to provide students' learning needs. In addition, teachers also have duty as mediators and provide recognition on the efforts that the students have done. The recognition will function as motivation for students to keep improving their potential so that their self-confidence will get higher. The growing self-confidence within students will give positive perception on the learning process that has been done. The optimistic attitude in solving problems will motivate students to use the concepts that they have to solve problems with different contexts (Fatimah et al., 2020; Hazadiyah et al., 2012).

The results of this study are in line with the research conducted by (Cetin, 2017) that states that self-regulated learning through life science courses can revise the perception on the learning of science. (Laura \& Phil, 2018) obtain the same results that self-regulated learning can grow students' selfconfidence when playing instruments. (Abdul \& Abidha, 2016) find out that the learning outcomes of the students learning with self-regulated learning aided by computated mathematics learning materials are 
very high.

In terms of students' cognitive style, self-regulated learning showed optimum results on individuals with FI because in self-regulated learning, dependence on the information given by the teachers is diminished and responsibility in learning is on students. Students learn more independently, work harder and are given chances to analyse their understanding on something. This condition can only be done by individuals with FI. The confidence of the students with FI will grow maximally if they learn with self-regulated learning model as this model will allow students to experience four processes of selfconfidence independently. The first process is cognitive process. This process is related to something that is constructed by someone in his/her mind. The cognitive process that students do in self-regulated learning is managing the learning activities that they do independently. Students will form learning process through the interaction with their groupmates. The second process is motivation process. The motivation process is done by students when they manage their learning. Their tasks and responsibilities are on their own. This enables students to grow their personal motivation in learning. The third one is affection process. When students manage themselves, the involvement of emotion is very important in learning. The psychiatric process that goes through in the learning process makes them confident in their ability. The fourth process is selection. Someone's ability to select options with his/her cognitive consideration will form higher confidence.

On the other hand, FD individuals did not show optimum results when they learnt with selfregulated learning. FB individuals are individuals that think globally. An object with its surrounding is seen as a unity so that the object will be influenced by its surrounding. FD individuals tend to receive the existing information as they lack ability to build a new structure from the information that they newly receive. The social orientation of FD individuals is very high and they easily build relationship with their surrounding, so their external motivation is their reinforcement. FD individuals tend to receive information generally and they often encounter difficulties connecting concepts with the real worlds. Teachers' guidance and direction are main priority for them. External reinforcement in the forms of rewards as stimulus can grow their motivation in learning. FD individuals love to work in mutual cooperation and togetherness atmosphere. A good learning condition for FD individuals is learning in group with strong interaction with classmates and teachers. The learning process needs instruction and guidance from teachers in details. Concepts are presented clearly then followed by examples of questions to gain better understanding. If self-regulated learning is given to them, it will be a burden for them; their conceptual understanding and self-confidence will not grow optimally.

This study is supported by some relevant researches: (1) a research done by (Melissa, 2016) shows that self-regulation can grow students' self-motivation in learning; (2) a research conducted by (Cetin, 2017) indicates that self-regulation can revise perception in learning; (3) a research by (Laura \& Phil, 2018) shows that self-regulation can grow students' self-confidence; (4) a research done by (Abdul \& Abidha, 2016) shows that self-regulation using computated mathematics learning materials results in good learning independence; (5) a research by (Woottipong, 2020) indicates that self-regulated strategy results in efficacy and performance in writing.

The implication of this study is that the implementation of learning model and cognitive style besides affecting sudents' understanding and self-confidence, can also motivate them to be more active in following the learning activities. This study indirectly has implication for the improvement of students' learning outcomes.

\section{Conclusion}

Based on the results of the study, it can be concluded that learning model and cognitive style can give significant impact on students' conceptual understanding and self-confidence. The impplication of this study is it can motivate students to be more active in following learning activities. This study indirectly has implication for the improvement of students' learning outcomes.

\section{References}

Abdul, G. K., \& Abidha, K. (2016). Self-regulated learning: a motivational approach for learning mathematics. International Journal of Education and Psychological Research (IJEPR), 5(3), 78 - 89. https://doi.org/https://files.eric.ed.gov/fulltext/ED577702.pdf

Anwar, R. B., Yuwono, I., As'ari, A. R., Sisworo., \& Rahmawati, D. (2016). Mathematical representation by students in building relational understanding on concepts of area and perimeter of rectangle. Academic Journals (Educational Research and Reviews), 11(21), 2002-2008. 
https://doi.org/https://files.eric.ed.gov/fulltext/EJ1119681.pdf

Bekomson, A. N., Amalu, M. N., Mgban, A. N., \& Kinsley, A. B. (2020). Interest in Extra Curricular Activities and Self Efficacy of Senior Secondary School Students in Cross River State, Nigeria. International Education Studies. https://files.eric.ed.gov/fulltext/EJ1261728.pdf

Bingol, T. Y., Batik, M. V., Hosoglu, R., \& Kodaz, A. F. (2019). Psychological resilience and positivity as predictors of self-efficacy. Asian Journal of Education and Training, 5(1), 63-69. https://files.eric.ed.gov/fulltext/EJ1202241.pdf

Candiasa, I. M. (2010). Statistik multivariat disertai aplikasi dengan SPSS. Singaraja: Universitas Pendidikan Ganesha.

Ceran, S. A., \& Ates, S. (2020). Conceptual understanding levels of students with different cognitive styles: an evaluation in terms of different measurement techniques. Eurasian Journal of Educational $\begin{array}{lllll}\text { Research, } & 8(8), & 149 & - & 178 .\end{array}$ https://ejer.com.tr/public/assets/catalogs/0076033001596714403.pdf

Cetin, B. (2017). The influence of pintrich's self-regulated learning model on elementary teacher candidates in a life science course. Journal of Education and Training Studies, 5(8), 113 - 127. https://doi.org/https://doi.org/10.11114/jets.v5i8.2460

Daryanto. (2005). Evaluasi pendidikan. Jakarta: Rineka Cipta.

Djaali. (2011). Psikologi Pedidikan. Jakarta: Bumi Aksara.

Fatimah, S. K., Efendi, R., \& Liliawati, W. (2020). Pengaturan Diri Peserta Didik Sma Terhadap Prestasi Akademik Pada Materi Usaha Dan Energi. Jurnal Pendidikan Fisika, 8(2). https://doi.org/http://dx.doi.org/10.24127/jpf.v8i2.3012

Ghufron, M. N., \& Risnawati, R. S. (2011). Teori-teori psikologi. Yogyakarta: Ar-Ruz Media.

Hazadiyah, D., Kardinah, N., \& Sunardi, I. (2012). Hubungan Antara Kompetensi Sosial Dan Kepercayaan Diri Pada Siswa. Psympathic: Jurnal Ilmiah Psikologi, 5(2). https://doi.org/https://doi.org/10.15575/psy.v5i2.2160

Laura, R., \& Phil, K. (2018). Adult beginner instrumentalists" practice, self-regulation, and self-efficacy: a pilot study. Journal of Education and Training Studies, 6(5). https://doi.org/https://doi.org/10.11114/jets.v6i5.2978

McCluskey, C., Mitchelmore, M., \& Mulligan, J. (2016). The role of reasoning in the Australian curriculum: Mathematics. Mathematics Education Research Group of Australasia, 447-454. https://files.eric.ed.gov/fulltext/ED572330.pdf

Melissa, N. L. (2016). Interaction effect of gender and motivational belief on self-regulated learning: a study at ICT-integrated school. Malaysian Journal of Learning and Instruction, 13(3), 25-41. https://www.researchgate.net/deref/http\%3A\%2F\%2Fdx.doi.org\%2F10.32890\%2Fmjli2016.13. 1.2

Nazir, M. (2003). Metode penelitian. Jakarta: Ghalia Indonesia.

Ningsih, Y. L. (2016). Kemampuan Pemahaman Konsep Matematika Mahasiswa Melalui Penerapan Lembar Aktivitas Mahasiswa (LAM) Berbasis Teori APOS Pada Materi Turunan. Edumatica: Jurnal Pendidikan Matematika, 6(1). https://doi.org/https://doi.org/10.22437/edumatica.v6i01.2994

Qohar, A., \& Sumarmo, U. (2017). Improving mathematical communication ability and self-regulation learning of Junior High School student by using reciprocal teaching. IndoMs. J.M.E, 4(1), 59-74. https://doi.org/https://doi.org/10.22342/jme.4.1.562.59-74

Santyasa, I. W. (2012). Pembelajaran inovatif. Singaraja: Universitas Pendidikan Ganesha.

Situmorang, Z. R. D., \& Latifah, M. (2014). Pengaruh Dukungan Sosial, Konsep Diri, Dan Strategi Pengaturan Diri Dalam Belajar Terhadap Prestasi Akademik. Jurnal Ilmu Keluarga Dan Konsumen, 7(3). https://doi.org/https://doi.org/10.24156/jikk.2014.7.3.154

Susanti, E. L., Sukestiyarno, Y. L., \& Sugiharti, E. (2012). Efektivitas Pembelajaranmatematika Dengan Metode Problemposing Berbasis Pendidikan Karakter. Unnes Journal of Mathematic Education, 1(1), 13-19. https://doi.org/https://doi.org/10.15294/ujme.v1i1.255 
Tezci, E., Sezer, F., Aktan, S., \& Gurgan, U. (2016). Do Lifestyle self-regulated learning strategies. Eurasian Journal of Educational Research, 6(5), 239-258. http://10.0.57.97/ejer.2016.65.14

Ulfah, N. M., Ulfah, N. M., Indrawati, S. A., \& Hidayat, D. R. (2012). Konseling Individual Pendekatan Behavioral (Token Ekonomi Dan Pengaturan Diri) Untuk Meningkatkan Penyesuaian Diri Belajar Siswa (Studi Single Subject Experiment Pada 1 Siswa SMP Negeri 6 Bekasi). Insight: Jurnal Bimbingan Dan Konseling, 1(1). https://doi.org/https://doi.org/10.21009/INSIGHT.011.09

Wang, C. H., Harrison, J., Cardullo, V., \& Lin, X. (2018). Exploring the relationship among international students' english self-efficacy, using english to learn self-efficacy, and academic self-efficacy. Journal of International Students, 8(1), 233-250. https://files.eric.ed.gov/fulltext/EJ1166753.pdf

Woottipong, K. (2020). Investigation into Thai High School learners' self-regulated learning skills, selfefficacy and writing performance. Research in Pedagogy, 10(1), 32-49. http://10.0.23.49/istrped2001032W 